Stanisław T. Zarzycki SAC ${ }^{1}$

\title{
Prawda o Bogu Stwórcy, stworzeniu i jego odnowie według Wyznań św. Augustyna
}

W myśli współczesnej wywodzącej się z oświecenia człowiek jest ukazywany jako miara wszechrzeczy, jako ten, który sam chce odpowiedzieć na pytanie o genezę świata i sposób urzeczywistnienia go, rozwój i postęp dokonujący się w nim. Pytanie jednak o to, co jest miarą człowieka, pozostaje bez odpowiedzi. Takiej odpowiedzi udziela Biblia i teologia bliższa człowiekowi. Zdaniem Gustawa Marteleta odradzająca się chrystologia nie uwzględnia faktu stworzenia bardziej od teologii ogólnej i za mało objaśnia stworzenie w świetle przymierza zrealizowanego w Chrystusie ${ }^{2}$. Problematyką pochodzenia świata, stworzenia zajmowali się już w starożytności filozofowie i Ojcowie Kościoła. W myśli filozoficzno-teologicznej św. Augustyna dzieło stworzenia człowieka i świata łączy się z dziełem zbawczym Boga tak, iż mówi on o ,ponownym stworzeniu” człowieka. W jaki sposób Augustyn doszedł do prawdy o Stwórcy oraz stworzeniu i jakie znaczenie odegrała ona w jego teologii? Czy jej zrozumienie miało wpływ na sposób ukazywania natury życia duchowego? Jakie znaczenie w objaśnieniu tego zagadnienia miała dla niego filozofia, a jakie Pismo Święte?

\section{Doniosłość tematyki stworzenia w Wyznaniach - terminologia}

Zasadniczym celem autora Wyznań podczas pisania autobiografii było oddanie chwały Bogu miłosiernemu za to, że wyrwał go z błędów i grze-

1 Dr hab. Stanisław T. Zarzycki SAC, prof KUL, pracownik Instytutu Teologii Duchowości na Wydziale Teologii KUL, adres e-mail: zastan@wp.pl, ORCID: 0000-0002-1566-6695.

2 Por. G. Martelet, Pierworodny wszelkiego stworzenia, „Communio” 2 (1982) z. 4, 18. 
chów, odnowił w nim łaskę wiary oraz tak przemienił jego życie, że stał się Jego sługą, pasterzem Kościoła. Z tym celem łączyło się wynikające z miłości bliźniego pragnienie, aby prawdę Bożą, którą Augustyn poznał, ukazać także tym, którzy jej szukają tak, by łaska Boża mogła dokonywać w ich życiu podobnych rzeczy ${ }^{3}$. W tym dziele, obok wątku doksologicznego i pedagogicznego, można dostrzec powiązany z nimi wątek dotyczący tematu stworzenia, tj. Boga Stwórcy, człowieka jako szczególnego stworzenia oraz całego wszechświata.

Już we wstępie do Wyznań, Bóg został wielokrotnie określony „Panem wszystkiego, co stworzone (Dominus omnium, quae creasti)" [...] Panem (Magnus es, Domine) godnym chwały" ze strony człowieka, który, choć jest zaledwie „cząsteczką stworzenia (aliqua portio creaturae tuae)", nie powinien milczeć o swym Bogu Stwórcy, lecz winien Go sławićs.

Człowiek jest ukazany w szerokim kontekście stworzenia będącego dziełem Boga Stwórcy, ,przez którego wszystko się stało”, „od którego wszystko pochodzi i dla którego" wszystko istnieje (1Kor 8,6; por. Rz 11,36) ${ }^{6}$. Według Augustyna człowiek z racji bycia stworzonym na obraz i podobieństwo Boże $(\operatorname{Rdz} 1,26)$ jest ontycznie ukierunkowany na Boga, czego znakiem jest m.in. wszczepiona w jego serce tęsknota za Nim i dążenie do zjednoczenia z Nim7. To dążenie staje się czynnikiem dynamicznym całej historii osobistej Augustyna od początku jego świadomych poszukiwań prawdy. Owa osobista historia pozostaje w związku z Bożym planem zbawienia ludzkości urzeczywistnianym w historii świata. Augustyn zauważa, że droga zbawienia człowieka przebiega niejako przez, ,środek świata” i że warunkiem zbawienia jest poddanie się woli Bożej i uzyskana zdolność panowania nad rzeczami tego świata.

Na określenie Boga Stwórcy Augustyn używa takich terminów, jak np.: „Stwórca wszystkich rzeczy (Creator rerum omnium)”, „Źródło życia [...] jedyny prawdziwy Stwórca i Rządca wszechświata (fons vitae [...] unus et verus creator et rector universitatis)" ${ }^{\prime \prime}$ itp. Na wyrażenie aktu stworzenia

\footnotetext{
3 Por. Augustinus, Retractationes 32, 6.

4 Augustinus, Confessiones I 6, 9. Na wstęp do pierwszej księgi składają się teksty Confessiones I 1-6.

5 Augustinus, Confessiones I 1, 1; 4, 4.

6 Por. Augustinus, Confessiones I 2, 2.

7 Por. Augustinus, Confessiones I 1, 1: ,Tu excitas, ut laudare te delectat, quia fecisti nos ad te et inquietum est cor rostrum, donec requiescat in te".

8 Augustinus, Confessiones I 10, 16; 3, 8.15; 7, 3-4; 8, 1-2; 9, 6.14; 12, 19.28.

9 Augustinus, Confessiones III 8, 16.
} 
używa takich czasowników, jak: creare $^{10}$, facere $^{11}$, instituire $^{12}$, jak również innych zbliżonych do nich, np. dare vitam ${ }^{13}$ itp. Na określenie człowieka jako stworzenia można znaleźć takie terminy, jak: creatura humana ${ }^{14}$, ani$m a l^{15}$ (w znaczeniu ,istota żywa").

Wyznania Augustyna dzielą się na dwie części: (1) biograficzną obejmującą (a) czas życia Augustyna od początku do przyjęcia chrztu (księgi I-IX) i (b) opis stanu jego duszy w czasie pisania Wyznań (księga X), tj. kilkanaście lat późnej oraz (2) egzegetyczną, czyli egzegezę pierwszych rozdziałów Księgi Rodzaju (księgi XI-XIII). Pojawia się tu pytanie: dlaczego w tym dziele autor połączył ze sobą tak różne zagadnienia? Problem ten stanowił i stanowi do dziś dla badaczy pism Augustyna niełatwą ,zagadkę", w rozwiązaniu której proponowane są różne objaśnienia ${ }^{16}$. Kwestia ta nie łączy się podejmowanym tu tematem, powoduje jednak pewną trudność powiązania teologii stworzenia dwóch odmiennych części analizowanego dzieła.

Rozpatrując dwie tematycznie odmienne części Wyznań, niektórzy teologowie dostrzegają pewne elementy, czy też wątki, które ich zdaniem zapewniają im zewnętrzną albo nawet i wewnętrzna jednośćc ${ }^{17}$. Luiggi Franco Pizzolato swą tezę o jednolitej strukturze Wyznań opiera się na analogii istniejącej pomiędzy sześcioma okresami życia Augustyna opisanymi w poszczególnych księgach jego autobiografii, czyli dzieciństwem (infantia - I 1-7), okresem chłopięcym (pueritia - I 8-20), okre-

10 Augustinus, Confessiones I 6, 9.

11 Augustinus, Confessiones I 2, 2. Częstotliwość tego czasownika jest większa w opisach stworzenia niż innych jego synonimów. Augustyn zamienia tu występujący w Wulgacie czasownik creare na facere. C. Mayer, Creatio, creator, creatura, AL II fasc. $1 / 2,64$.

12 Augustinus, Confessiones XI 5, 7.
13 Augustinus, Confessiones I 7, 11.
14 Augustinus, Confessiones IV 12, 19.
15 Augustinus, Confessiones I 6, 10.

16 Por. E. Feldmann, Confessiones, AL I fasc. 7/8, 1143-1153.

17 Analizując je i porządkując, Feldman proponuje sześć dróg, na których można szukać powiązania dwóch odmiennych części Wyznań: (1) obecność confessio w całym dziele; (2) powiązanie treści owych części z sytuacjami życiowymi Augustyna (np. wpływ manicheizmu i jego próba ustosunkowania się do niego); (3) podobieństwo w obu częściach odnośnie do stawianych problemów (np. obecność i działanie Boga w życiu Augustyna); (4) rola Pisma Świętego w życiu Augustyna, a zwłaszcza Księgi Rodzaju i obecność wątku stworzenia w jego wcześniejszej modlitwie; (5) odwoływanie się w obu partiach do licznych wersetów przejętych z Księgi Psalmów; (6) porównanie stylu literackiego, gatunków literackich w obu częściach. Por. Feldmann, Confessiones, AL I fasc. 7/8, 1140-1153. 
sem dorastania (adolescientia - II-VI), wiekiem młodzieńczym (iuventus - VII-IX), przejściem z okresu młodzieńczego do okresu poważnego (declinatio a iuventute ad [...] gravitas $-\mathrm{X}$ ) i wiekiem starszym (senectus - XI-XIII), a sześcioma dniami stworzenia analizowanymi przez Augustyna w komentarzu do Księgi Rodzaju ${ }^{18}$. Twierdzi, że ta analogia została zamierzona. Włoski autor uważa, że zauważone przez niego elementy Wyznań zapewniają im jednoczącą strukturę i że w jej ramach należy rozpatrywać confessio oraz jej stopniowy rozwój w postawie moralno-duchowej Augustyna. Pozwala on zachować wymiar historii stworzenia i zbawienia, „której częściami są wszystkie ludzkie żywoty" 19 i która jest podstawą zarówno do analizy nauki o stworzeniu w ostatnich trzech księgach Wyznań, jak i do badania biografii duchowej Augustyna.

W analizie wątku stworzenia zostaną uwzględnione te okresy życia Augustyna, w których pojawia się to zagadnienie.

\section{Droga poszukiwania prawdy o Stwórcy i stworzeniu}

Prawda o człowieku jako stworzeniu, a także prawda o świecie są ściśle powiązane z prawdą o Bogu, gdyż jedynie w odniesieniu do Boga człowiek, stworzenie rozumne, pojmuje „skąd” jest i „dokąd” zmierza on $\mathrm{i}$ ten świat. Jaką naukę zawierają Wyznania o naturze stworzenia i teologii stworzenia?

Dziękując za początek swego życia, Augustyn wyznaje: „zostałem poczęty i w grzechach nosiła mnie w łonie matka (Ps 50,7)" 20 , ,zostałem ukształtowany w czasie (formasti in tempore) przez Boga" ${ }^{21}$. „Ty uczyniłeś niebo i ziemię, to niebo, które widzę, i tę ziemię, po której chodzę, i z której jest też ta odziewająca mnie ziemia: to moje ciało też uczyniłeś (haec terra quam porto. Tu fecisti)"22. Bóg Stwórca poprzedza człowieka w istnieniu. Augustyn podkreśla niejednokrotnie, że motywem aktu stworzenia jest dobroć Boża ${ }^{23}$. To ona, dodaje, ,wyprzedziła to wszyst-

18 Por. L.P. Pizzolato, Le „Confessioni” di Sant'Agostino. Da biografia a 'confessio', Milano 1968, 63.

19 Augustinus, Confessiones XI 28, 38.

20 Augustinus, Confessiones I 7, 12.

21 Augustinus, Confessiones I 6, 7.

22 Augustinus, Confessiones XII 2, 2.

23 Por. Augustinus, Confessiones I 12, 19; 19, 30; II 6, 13; 10, 18. 
ko, czym uczyniłeś mnie [Boże] i z czego mnie uczyniłeś"24. Dziękuje Bogu za to, że obsypał go licznymi dobrami naturalnymi, zdolnościami ujawniającymi się już w dzieciństwie, np. pamięcią, zdolnością posługiwania się językiem łacińskim itp. „Takie stworzenie jakże zadziwiające posiadało właściwości" ${ }^{25}$. Czyni sobie jednak wyrzuty, że wówczas nad naukę przedkładał zabawy, gry, wskutek czego w szkole retoryki, w której panowała bardzo surowa dyscyplina, otrzymywał kary fizyczne. Krytykuje zarazem system kształcenia i wychowania w swej szkole inspirowany mitologią i poezją rzymską, sprzyjający swobodzie obyczajów. Podsumowując tamten czas wyznaje: „nie w Bogu, ale w stworzeniach, w sobie i w innych, szukałem radości, wzniosłości i prawdy"26. Bóg jednak ,milczał” i „rozpalał się gniewem” na Augustyna, ale go nie porzucał. „Nie jest bowiem odległa od nas wszechmoc Twoja nawet wtedy, gdy my daleko od Ciebie odchodzimy" ${ }^{27}$. Wskutek tego odchodzenia od Boga „uczuciem” Augustyn popadał w udrękę duchową, psychiczną, której nic nie mogło ukoić. Nie było to świadome zerwanie więzi z Bogiem, ale raczej młodzieńczy „bunt” przeciw normom społecznym, chęć zakosztowania wolności skutkująca jej częściową utratą i przylgnięciem do stworzeń. Augustyn twierdzi, że nawet ci, co odrywają się od Boga, wskutek wewnętrznego podobieństwa do Boga przewrotnie Go naśladują i dają świadectwo temu, ,że [...] jest natury Stwórcą i że to, co by zupełnie oderwało się od [Boga], w ogóle przestałoby istnieć" 28 .

Kryzys religijno-moralny w życiu Augustyna jeszcze bardziej się nasilił, gdy podjął on w Kartaginie studia sztuki oratorskiej. Wówczas buntował się przeciw „opiece Boga” i wpadał w sidła namiętności, a jego dusza zaczęła „,chorować”, okrywając się „,wrzodami”. Poszukiwał ciągle nowych wrażeń w świecie zewnętrznym (proiciebat se foras) ${ }^{29}$. Wtedy to studiując dzieła oratorskie, natrafił na książkę Hortensjusz Cycerona, która nie tylko go poruszyła, ale tak na niego wpłynęła, że wzbudziła w nim dwa duchowe pragnienia: (a) silne pragnienie modlitwy i powrotu do Boga, czemu daje wyraz w słowach: ,Jakże gorąco pragnąłem odlecieć od rzeczy ziemskich do Ciebie!”; (b) „,pragnienie nieśmiertelności”, które zamierzał urzeczy-

24 Augustinus, Confessiones XIII 1, 1: ,[...] priusquam essem tu eras, nec eram, cui praestares ut essem, et tamen ecce sum ex bonitate tua praeveniente totum hoc, quo me fecisti et unde me fecisti.

25 Augustinus, Confessiones I 19, 30: „Quid in tali animante non mirabile atque laudabile?".
26 Augustinus, Confessiones I 19, 30.
27 Augustinus, Confessiones II 2, 2.
28 Augustinus, Confessiones II 6, 14.
29 Augustinus, Confessiones III 1-2. 
wistnić przez filozoficzne poszukiwanie mądrości ${ }^{30}$. To drugie pragnienie motywowane pierwszym zapowiada, w jaki sposób Augustyn będzie później pojmował mądrość, a mianowicie jako ,intelektualne poznanie rzeczywistości wiecznej"31.

Skutkiem tego przeżycia było osłabienie w jego sercu „ambicji światowych" i odzyskanie pewnej wolności względem rzeczy ziemskich ${ }^{32}$. Ten przełom w życiu Augustyna bywa określany nawróceniem ${ }^{33}$. Nie uzyskało ono jednak charakteru ściśle religijnego, lecz jedynie intelektualny, gdyż, jak się wydaje, zabrakło kogoś, kto mógłby Augustynowi ukazać Chrystusa. Łaska, której wtedy doświadczył, ożywiła w nim pragnienie poznania Chrystusa, o którym jako dziecko wiele słyszał w domu rodzinnym, zwłaszcza w czasie, gdy miał przyjąć chrzest, dlatego też w owej książce poszukiwał wzmianki o Chrystusie, ale jej nie znalazł. Sięgnął wówczas do Pisma Świętego, aby je lepiej ,zbadać”. W porównaniu jednak z „,monumentalną prozą" Cicerona wydało mu się stylistycznie zbyt proste i za mało dostępne w sensie duchowym ${ }^{34}$.

Taka ocena Pisma Świętego przez Augustyna świadczy o jego intelektualnym podejściu, pozbawionym pobożności.

Kierowany przekonaniem, że jedynie mądrość powinna być kochana, mądrość filozoficzna, Augustyn uległ wkrótce tym, którzy obiecywali mu rychłe poznanie prawdy, tj. manichejczykom ${ }^{35}$. Przylgnął do tej sekty $z$ nadzieją, iż spotka tam osoby, z którymi nawiąże dialog pozwalający mu na głębsze odkrycie prawdy o świecie i Bogu uzyskiwanej rozumem. Po latach określi manichejczyków jako ludzi „,pogrążonych w sensualizmie

30 Por. Augustinus, Confessiones III 4, 8.

31 Augustinus, Div. qaest. ad Simpl. 2, 3, PL 40, 140: „Sapientia pertinet ad intellectum aeternorum, scientia vero ad ea, quae sensibus corporis experimur".

32 Por. Augustinus, Confessiones III 4, 8.

33 Por. J.O. Reta, Aspects théologique de la conversion, StPatr 33 (1997) 209.

34 Por. Augustinus, Confessiones III 5, 9.

35 Manicheizm wywodzący się od Maniego (III wiek) był postacią gnostycyzmu, nie elitarnego, ale uniwersalnego, nastawionego na działalność misyjną i przepowiadanie Prawdy. Cechował go synkretyzm, gdyż czerpał z ksiąg wielu religii i mądrości pokoleń. Głosił kosmologiczno-antropologiczny dualizm, czyli istnienie dwóch przeciwstawnych, jednakowo wiecznych i zwalczających się materialnych pierwiastków: światła (dobra) i ciemności (zła) walczących ze sobą o człowieka. W świecie światłości rządzi Bóg, w świecie ciemności natomiast - szatan. Człowiek ma dwie dusze: jedną rodzącą dobre myśli, uczucia i czyny, przez którą jednoczy się z Bogiem, drugą ulegającą złu przychodzącemu od strony ciała. Człowiek jest skazany na ciągłą walkę duchową i grozi mu zniewolenie przez pożądania zmysłowe. Wyzwolenie od zła jest możliwe jedynie dzięki zdobyciu wyższego poznania i przestrzeganiu zasad moralności. Zob. J. Legowicz, Historia filozofii starożytnej Grecji i Rzymu, Warszawa 1986, 414-418. 
i gadulstwie", rozprawiających więcej o żywiołach świata niż o Bogu, skupiających się bardziej na pięknych dziełach zewnętrznych Boga, jak słońce i księżyc, niż na Jego dziełach duchowych, które są ważniejsze ${ }^{36}$. Słońce dla uczniów Manesa było miejscem eonów wybawicielskich, a księżyc siedzibą „Matki Życia”, z której wyłonił się praczłowiek. Ku tym planetom zwracali się zwolennicy Manesa, wierząc, że stamtąd pochodzi światło będące źródłem zbawienia ${ }^{37}$. Augustyn nie miał jeszcze wówczas ukształtowanych poglądów o Bogu. Dlatego łatwowiernie przyjął ich teorię, według której Bóg jest „ciałem świetlistym i bezmiernym” (corpus [...] lucidum et inmensum), a człowiek ,małym kawałkiem oderwanym od tego ciała (frustum de illo corpore)"38. Boga pojmował

jako ogarniającego [materię świata] ze wszystkich stron i przenikającego ją w każdej części, a zarazem pod każdym względem nieskończonego. Tak jakby rozlewało się wszędzie morze i nie było nic innego oprócz bezmiernego, nieskończonego morza, a gdzieś w jego obrębie byłaby gąbka, wielka, lecz jednak ograniczona, napełniona we wszystkich swoich częściach przez owo bezmierne morze ${ }^{39}$.

Owa „substancja” [Boga] nie podlegała według niego zepsuciu, ubytkowi czy zmianie ${ }^{40}$. Takie wyobrażenie Boga odpowiadało Augustynowi bardziej niż to, które mu wmawiali manichejczycy o Bogu chrześcijan, iż „ma kształt ciała ludzkiego, [jest] ograniczony zarysami takich członków, jak my mamy"41. Tak opatrznie pojmowali oni wcielenie i oskarżali chrześcijan, iż wierzą w Boga cielesnego. Później Augustyn stwierdzi, że to pycha kazała mu głosić, iż jest z natury tym, czym jest Bóg. Nie wiedząc, że Bóg jest duchem $(\mathrm{J} 4,24)$, akceptował materialistyczne rozumienie Boga.

W ramach owego systemu filozoficzno-religijnego skłaniał się ku teorii emanacji. A oto jego opis wyobrażeniowy „kształtu” świata:

[...] całe Twoje stworzenie - zarówno to, co możemy zobaczyć: ziemię, morze, powietrze, gwiazdy, drzewa i żywe istoty śmiertelne, jak i to, czego ujrzeć nie można: utwierdzenie nieba w górze, wszystkich aniołów, wszystkie duchowe byty nieba [...] wyobrażałem sobie jako wielką masę składającą się z różnych rodzajów ciał [...] Pojmowałem tę masę jako olbrzymią, nie mo-

\footnotetext{
36 Por. Augustinus, Confessiones III 6, 10.

37 Por. Legowicz, Historia filozofii starożytnej, s. 416.

38 Augustinus, Confessiones IV 16, 31.

39 Augustinus, Confessiones VII 5, 7.

40 Por. Augustinus, Confessiones VII 1, 1.

41 Augustinus, Confessiones V 10, 19.
} 
gąc oczywiście znać jej rozmiarów, lecz wyobrażając ją sobie jako dowolnie wielką, chociaż we wszystkich kierunkach ograniczoną ${ }^{42}$.

Za czasów Augustyna panowała jeszcze kosmologia Ptolemeusza, według której wyobrażano sobie kosmos jako sfery krążące wokół ziemi osadzonej w centrum. Ten obraz można zakładać u podstaw podanego wyobrażenia.

Drugim poważnym błędem Augustyna, powiązanym ściśle z pierwszym, było to, że nie wiedział, skąd się bierze zło i skłaniał się do ontycznego dualizmu manichejskiego.

Także zło uważałem za substancję, za olbrzymią, bezkształtną, wstrętną masę materii, która mogła mieć postać stałą - wtedy manichejczycy nazywali ją ziemią - albo rozrzedzoną i ulotną, jak powietrze. Według ich wyobrażeń zło w tej drugiej postaci jest złowrogą myślą przenikającą ziemię. A ponieważ nawet ta odrobina pobożności, jaka była we mnie, uniemożliwiała mi przyjęcie mniemania, jakoby Bóg, dobrym będąc, stworzyć mógł jakąkolwiek naturę złą, wyobrażałem sobie, że przeciwstawiają się sobie nawzajem owe masy materii, przy czym obie są nieskończone, lecz zła w mniejszym, a dobra w większym stopniu ${ }^{43}$.

Co do prawdziwości tego dualizmu Augustyn żywił wątpliwości i dyskutował na ten temat z przyjaciółmi w Kartaginie i, jak twierdzi, przekonywał go argument Nebrydiusza. Ten formułował następującą supozycję. Jeśliby manichejczycy dopuszczali jakąś szkodę w Bogu wskutek wyrządzonego Mu zła przez negatywną masę materii, oznaczałoby, iż ukazują Boga naruszalnego i zniszczalnego, a więc nieprawdziwe$\mathrm{go}^{44}$. Augustyn szukał i nie znajdował źródła pochodzenia zła. Obecność i działanie tak potężnego pierwiastka materialnego, o którym mówili manichejczycy, mogły rodzić w nim przekonanie, że to nie ludzie grzeszą, ale że ,grzeszy w nich jakaś obca im natura" ${ }^{45}$. Czy to nazbyt proste rozwiązanie problemu zła sprzyjało wyzwoleniu się z pożądań zmysłowych czy raczej było dla Augustyna swego rodzaju usprawiedliwieniem? Coraz bardziej popadał $\mathrm{w}$ zniewolenie zmysłowe i nie znajdował $\mathrm{w}$ jego doświadczeniu „ukojenia”, nie mógł też o własnych siłach powrócić do Boga. Ten swój stan tłumaczy nieposłuszeństwem wobec Stwórcy i Rządcy świata, który poddał człowiekowi wszystkie rzeczy i sytuacje

\footnotetext{
42 Augustinus, Confessiones VII 5, 7.

43 Augustinus, Confessiones V 10, 20.

44 Por. Augustinus, Confessiones VII 2, 3.

45 Augustinus, Confessiones V 10, 18.
} 
oraz polecił mu nad nimi panować. Owo panowanie uzależnił jednak od posłuszeństwa człowieka.

Również swe doświadczenie etyczne rozpatrywał Augustyn w ramach manicheizmu. Czyn niegodziwy określał jako „rozdarcie” serca, jako „dyadę", która miałaby się składać z pasji prowadzącej do przemocy i z żądzy będącej źródłem rozpusty. Cnotę moralną natomiast definiował jako „pewnego rodzaju jedność” umysłu, „monadę"46. W tych poszukiwaniach koncentrował się zbytnio na swym subiektywnym doświadczeniu, a pomijał obiektywne elementy wady i cnoty, czego jeszcze nie był świadomy. Na sposób jego rozumowania rzutowało w dużej mierze zbytnie pogrążenie się w namiętnościach, wskutek których jego „myśli rozgoraczkowane” bardziej szukały barw i kształtów przedmiotów niż bytów bezcielesnych ${ }^{47}$. „Dawałem się unosić na fali, zmierzając ku rzeczom, które nie istnieją w ogóle - ani w Tobie, [Boże], ani we mnie, ani w materii. Nie stworzyła ich dla mnie Prawda Twoja, lecz wymyśliła je - biorąc za punkt wyjścia rzeczy materialne - niedorzeczna fantazja" ${ }^{48}$. Czy nie mamy tu do czynienia $\mathrm{z}$ epistemologicznym sensualizmem, obecnym w manicheizmie, odwołującym się nie tylko do poznania racjonalnego, ale i do obrazów natury oraz mitów, który dołącza się do racjonalnego poznania, szczególnie wtedy, gdy rozum ulega sile namiętności? Wtedy poznanie zmysłowe, dostarczając wrażeń i obrazów, narzuca się poznaniu racjonalnemu z większą siłą i w jakiejś mierze je determinuje. „Prawdziwą piękność [cnoty] dostrzega wewnętrzne oko duszy, a nie oko fizyczne"49, czyli zmysł wewnętrzny, duchowy, a nie zewnętrzny.

Augustyna przynależność do manicheizmu kończy się rozczarowaniem z kilku powodów. Najpierw dlatego, że w pismach Manesa, a potem w rozmowie $\mathrm{z}$ biskupem manichejskim Faustusem nie uzyskał wyjaśnienia prawdy o świecie i wytłumaczenia zjawisk astronomicznych (zaćmienie słońca, księżyca itp.), którymi się interesował i czytał o nich w dziełach niektórych filozofów ${ }^{50}$. Filozofia $\mathrm{w}$ starożytności miała za przedmiot nie tylko szukanie prawdy rozumowej (ratio intellegendi) i moralność (ordo vivendi), ale także świat otaczający, poszukiwała jego ostatecznych racji bytu (causa subsistendi). Również brak niezmiennej zasady dobra (wspo-

\footnotetext{
46 Augustinus, Confessiones IV 15, 24.

47 Augustinus, Confessiones IV 15, 24.

48 Augustinus, Confessiones IV 15, 24.

49 Augustinus, Confessiones VI 16, 26.
}

50 Por. Augustinus, Confessiones V 3, 4. Augustyn nie podaje imion tych filozofów, przyznaje jednak, że ich opisy świata i jego praw zawierają „wiele trafnych opinii”, są pomocne, gdy chodzi o obliczenia dokładnego czasu zaćmienia słońca i księżyca. 
mniany argument Nebrydiusza) czynił w oczach Augustyna manicheizm religijnie i moralnie niewiarygodnym.

Porzucając manicheizm, Augustyn porzucił także astrologię i astrologów, u których niekiedy szukał rady. Jego zdaniem astrologowie nie kierują się normami moralnymi, ale wmawiają temu, kto poszukuje przezwyciężenia własnych problemów moralnych i wiedzy o przyszłości, że: „Niebo obarczyło cię przymusem grzeszenia" ${ }^{51}$, tzn. że przeznaczenie człowieka zapisane jest $\mathrm{w}$ gwiazdach i że, w konsekwencji, nie od niego zależy jego życie, ale od takiego czy innego układu planet.

Po zerwaniu z maicheizmem w Kartaginie Augustyn wyjechał do Rzymu i tam po krótkim kontakcie z tą sektą popadł w pewien sceptycyzm wynikający z tego, że tak długo na swej „krzywej drodze” życiowej nie znalazł prawdy. Zaczął powątpiewać w to, czy jej znalezienie jest w ogóle możliwe. Pewne uprzedzenia do katolicyzmu przyjęte od manichejczyków nie pozwalały mu na powrót do wiary swej matki. Wtedy bliżsi stali się mu akademicy ${ }^{52}$, którzy twierdzili, że „o wszystkim należy wątpić i że człowiek nie jest zdolny do poznania czegokolwiek w sposób pewny"53. Tę tezę Augustyn przez krótki czas podziela154, a następnie, najprawdopodobniej pod wpływem dalszych lektur, ocenił krytycznie i odrzucił.

\subsection{Zwrot ku sobie i laska poznania Stwórcy i sensu stworzenia}

Nie ustając w poszukiwaniu prawdy, Augustyn sięgał do książek filozofów neoplatońskich tłumaczonych z greki na łacinę ${ }^{55}$. W pismach tych znalazł naukę o Słowie Bożym, przejętą z prologu Ewangelii według św. Jana, niekompletną jednak, gdyż pozbawioną wzmianki o śmierci krzyżowej i zmartwychwstaniu Jezusa Chrystusa oraz prawdy, że tym, którzy w Niego uwierzyli, udziela On mocy, aby się stali dziećmi Bożymi

51 Augustinus, Confessiones IV 3, 4.

52 Chodzi o filozofów nowej Akademii Cycerona nawiązującej do Akademii Platońskiej, którą tworzyli m.in. Arkezilaos z Pitane (316-241), Karneades z Cyreny (214129/8), Filon z Laryssy (110-80) i Antiochos z Askalonu. Św. Augustyn znał ich sceptyczne poglądy na podstawie Ksiag akademickich Cycerona i skrytykował je w dziele Przeciw Akademikom.

53 Augustinus, Confessiones V 10, 19.

54 Por. Augustinus, Contra Academicos II 23.

55 Por. Augustinus, Confessiones VII 9. Według A. Trapè na podstawie dialogów z Cassiciacum da się ustalić, iż chodzi o Eneady Plotyna i kilka dzieł Porfiriusza (m.in. De regressu animae). Por. A. Trapè, Introduzione, w: Sant'Agostino. Le Confessioni, red. M. Skutella, tł. C. Carena, Roma 1965, LXVI. 
(J 1,1-12 $)^{56}$. Fakt, iż Augustyn potrafił porównać teksty platońskie z Ewangelią i wychwycić między nimi szczegółowe różnice, wskazuje na jego ponowne zainteresowanie się Pismem Swiętym, którego objaśnień zaczął słuchać w Mediolanie, po przeniesieniu się tam z Rzymu. Długo uznawał Chrystusa ,tylko za człowieka wyposażonego w niezwykłą mądrość", za nauczyciela, tłumacząc sobie, iż Słowo Boże, które nie może podlegać żadnej zmianie, jeśliby złączyło się z ciałem, stało by się $z^{2 m i e n n e}{ }^{57}$. Boski „Logos” platoński, który był mu ciągle bliski, był niematerialny, niezmienny i wieczny. Na etapie do nawrócenia nie znajdujemy modlitw Augustyna skierowanych do Chrystusa, a jedynie ogólnie do Boga. W listach św. Pawła zastanawiało go, iż apostoł dziękuje Bogu za łaskę poznania prawdy Chrystusowej i trwanie w Jego miłości, i że wzywa do wdzięczności Bogu (1Kor 4,7), co Augustyn uznał za słuszne i godne naśladowania.

Książki neoplatońskie zachęcały go do powrotu do samego siebie, do głębi swej istoty, co zaczął praktykować. Skoro po latach oceni, że wówczas był „wspomagany” łaską Bożą, należy przyjąć, iż wtedy owe ćwiczenia duchowe prowadził nie tylko w duchu neoplatońskim, licząc jedynie na własne siły. Wyznaje, iż zostało mu udzielone szczególne doświadczenie duchowe: ,[...] wszedłem tam i takim wzrokiem duchowym, jaki był mi dany, dojrzałem w górze (entravi et vidi), ponad owym wzrokiem, ponad moim umysłem światłość Boga niezmienną (supra mentem meam lucem inconmutabilem)" 58 . Odtąd Bóg będzie dla Augustyna „Światłem prawdy" w sensie mistycznym. Doświadczenie to nie polegało jedynie na dojrzeniu światła Bożego, ale i na silnym doznaniu go w sobie (radians in me vehementer), co nie pozostanie bez wpływu na nowy sposób widzenia prawdy ${ }^{59}$. Oto dlaczego Augustyn pisze dalej, iż zrozumiał, że ta światłość „w górze” jest tą, „która [go] stworzyła (superior, qui ipsa fecit me)”, a że on będąc niejako „na dole”, ,został przez nią stworzony (inferior, quia factus ab ea)". W owym momencie uzyskał nowy sens genezy swego życia, sens stworzenia, który od razu zaczął konfrontować z tym sensem, który dotychczas przyjmował, i dlatego w duchu manichejskim zadał sobie pytanie: „Czy Prawda jest niczym, skoro nie przysługuje jej rozciągłość w przestrzeni?”. W tym pytaniu wykroczył myślą poza materię i przestrzeń, ale owa sfera transcendencji wydała mu się „nicością”. W odpowiedzi usłyszał w głębi własnego serca głos Boży: „To jam jest

\footnotetext{
3 Por. Augustinus, Confessiones VII 9, 13-14.

57 Por. Augustinus, Confessiones VII 19, 25.

58 Augustinus, Confessiones VII 10, 16.

59 Por. Augustinus, Confessiones VII 10, 16.
} 
Tym, który jest $(\mathrm{Wj} 3,14){ }^{\prime 60}$. Ogarnęła go całkowita pewność poznania Prawdy poprzez rzeczy stworzone ${ }^{61}$. To doświadczenie pozwoliło mu przyjąć do serca słowa, które Mojżesz usłyszał pod górą Horeb (Wj 3,14) i określenie Boga jako „Tego, który nie tylko w takiej czy innej mierze istnieje, lecz jest samym bytem"62.

Objaśniając owo tajemnicze imię Boga objawione Mojżeszowi, Augustyn mówi o Bogu Stwórcy jako ,prawdziwym i nieodmiennym bycie”, w porównaniu z którym „wszystkie rzeczy nie istnieją”, „są”, ale „nie istnieją" "63. Dla wyjaśnienia tej kwestii używa następującego porównania: ,jak dobrem dóbr jest dobro", tak racją istnienia wszystkich rzeczy jest „dobry Pan” ${ }^{4}$. Według Etienne Gilsona „być” i „,niezmienny” funkcjonują w pismach Augustyna jako synonimy, podobnie jak terminy ,niezmienność" i ,wieczność” Boga oznaczają to samo, co „ten sam [Bóg]” (Ps 101,28): „Ty zaś jesteś zawsze ten sam i lata Twoje nie mają końca”. W tym wyraża się esencjalizm augustyński ${ }^{65}$.

Uwydatniona tu zasada uczestnictwa rzeczy istniejących w absolutnym istnieniu Boga podkreślana była także przez neoplatoników ${ }^{66}$. Przez Augustyna była jednak rozumiana, jak się wydaje, w duchu chrześcijańskim. Świadczy o tym fakt, iż wymienione przeżycie mistyczne i lektury pism neoplatończyków nie skłoniły go do zaakceptowania ich systemu filozoficznego w całości, ale że przejawiał wobec nich postawę krytyczną. Negatywnie oceniał fakt, iż ,prawdę Bożą przemienili w kłamstwo i stworzeniu oddawali cześć, i służyli mu, zamiast służyć Stwórcy" (Rz 1,25) ${ }^{67}$, czyli że dopuszczali się bałwochwalstwa.

Medytując nad doznaną przelotną ekstazą, Augustyn zrozumiał, że wszystkie rzeczy skończone istnieją w Bogu (in te cuncta finita), jednak nie tak, jak dotychczas myślał, że istnieją w Nim jak w przestrzeni, ale

60 Augustinus, Confessiones VII 10, 16.

61 Por. Augustinus, Confessiones VII 10, 16.

62 Augustinus, Confessiones XIII 31, 46: ,[... ] ab illo enim est, qui non aliquo modo est, sed est, est".

63 Augustinus, Confessiones VII 11, 17.

64 Augustinus, Enarrationes in Psalmos, Ps 134, 4.

65 „Tu autem idem ipse es, et anni tui non deficient”. Por. E. Gilson, Notes sur l'être et le temps chez Saint Augustin, ,Recherches Augustiniennes”, II. Supplement à la „Revue des Sciences des Études Augustiniennes", Paris 1962, 206.

66 Por. Augustinus, De civitate Dei VIII 9: „Którzybykolwiek filozofowie mieli o Bogu zdanie, że jest On i sprawcą rzeczy stworzonych, i światłem rzeczy, co mają być poznane, i dobrem w stosunku do tego, co ma być uczynione, czyli że od Niego mamy i początek przyrody, i prawdę nauki, i szczęśliwość życia”.

67 Augustinus, Confessiones VII 9, 15. 
istnieją w Nim w tym sensie, że jest On zasadą, przyczyną ich istnienia ${ }^{68}$. W tym przypadku Bóg, który wcześniej udzielił Augustynowi światła, jawi się jako podstawa skończonej rzeczywistości i daje się pojąć jednoznacznie jako Stwórca ${ }^{69}$.

Poznanie Boga Stwórcy dało Augustynowi możliwość głębszego wglądu w naturę stworzeń. Co nowego poznał o nich w świetle Bożym? Już w młodości po utracie przyjaciela Augustyn twierdził, iż życie ludzkie z woli Bożej podlega prawu zaistnienia, wzrostu do określonej pełni i zmierza ku nieistnieniu, jest zmienne, przemijające. Po uzyskaniu światła uznał, że to samo odnosi się do wszystkich rzeczy tego świata. Dostrzegł, że rzeczy „,nie istnieją w sposób zupełny [...] Są rzeczywiste w takiej mierze, w jakiej od [Boga] pochodzą, w jakiej [od Niego] czerpią istnienie, lecz są nierzeczywiste w tym znaczeniu, że nie są tym, czym [jest Bóg]"70" Wielokrotnie będzie podkreślał, że wszystkie rzeczy skończone przez fakt, iż się zmieniają i przekształcają, ,wołają" do człowieka, iż zostały stworzone, że to ich zmienne istnienie jest ,dowodem” na to, że zostały stworzone i że obecny jest ich Stwórca ${ }^{71}$. Tak różnią się sposobem istnienia i swą naturą od boskiego prawdziwego i niezmiennego bytu, że w porównaniu z Nim „W ogóle nie mają piękności, ani dobra, ani bytu”72. Jest to wynikiem tego, że choć pochodzą od Boga Stwórcy, zostały stworzone z niczego. Ten ich sposób istnienia pozbawiony istoty, sądzi Gilson, Augustyn wyraża językiem zbliżonym do współczesnego nam terminu „egzystencja” ${ }^{\prime \prime 3}$, choć to pojęcie nie istniało $\mathrm{w}$ starożytności ${ }^{74}$. Augustyna uderza w świecie to, że przy owej zmienności ten świat istnieje, a „braki”, które zauważa w bytach

68 Por. Augustinus, Confessiones VII 15, 21.

69 Por. G.L. Müller, Doświadczenie Boga jako początek wiary chrześcijańskiej, „Communio" 16 (1996) z. 5, 106.

70 Augustinus, Confessiones VII 11, 17.

71 Por. Augustinus, Confessiones XI 4, 6. Niektórzy znawcy Augustyna mówią o sformułowanym przez niego argumencie kosmologicznym za istnieniem Boga. Szerzej zob. S. Kowalczyk, Człowiek i Bóg w nauce św. Augustyna, Warszawa 1987, 208-213.

72 Augustinus, Confessiones XI 4, 6.

73 Dziś termin ,egzystencja” (od łac. existere - 'występować, okazać się, istnieć’) w ramach filozofii klasycznej jest rozumiany jako istnienie (esse), które jest podstawowym, niesamodzielnym, wewnętrznym pryncypium bytu niekoniecznego aktualizującym jego istotę (essentia, czyli to, co bytuje), czyniąc go realnym. Jest ona określona przez refleksyjność człowieka w konstytuowaniu swej tożsamości, aktualnie podejmowane przez niego decyzje życiowe, relacyjność, tj. odniesienie do otaczającej rzeczywistości i zajmowaną postawę wartościującą. Por. A. Wawrzyniak, Egzystencja, w: Leksykon Filozofii Klasycznej, red. J. Herbut, Lublin 1997, 138.

74 Por. E. Gilson, Notes sur l'être et le temps chez Saint Augustin, „Recherches Augustiniennes" 2 (1962) 210-211. 
skończonych, są dla niego apelem, wezwaniem do rozważania stwórczego aktu Bożego. Tak bardzo „przemawiało” do niego stworzenie i kierowało go na Stwórcę.

Augustyn podaje też stopnie opisanego doświadczenia duchowego: przechodzi w nim myślą od rzeczy materialnych do duszy poznającej świat przez zmysły", od duszy przechodzi do jej wewnętrznej mocy, dalej od jej zdolności rozumowania, od osądu faktów postrzeganych przez zmysły cielesne przechodzi do pragnienia zrozumienia samej siebie i stąd w momencie ekstazy wznosi się, a raczej zostaje podniesiony, do „wiecznej, niezmiennej prawdy"75. Według niektórych komentatorów wzorcem dla Augustynowej conversio in se ipsum jest Plotynowa koncepcja wznoszącej się świadomości prowadzącej do poznania własnego ,ja” (nous), a w końcu do doznania dotknięcia przez Jednego, czyli przechodzenia po kolei stopni świadomości aż do oświecającej ją zasady początku ${ }^{76}$. Biorąc jednak pod uwagę fakt, iż w opisie owego doświadczenia duchowego jest mowa o „byciu wspomaganym” przez Boga oraz o usłyszeniu głosu Bożego, trzeba przyjąć, iż zbiegają się tu dwa doświadczenia Augustyna, czyli że inspiracja i nauka neoplatońska otwierają mu „drogę wstępującą” do spotkania z Prawdą Bożą objawioną i ta go oświeca.

Pod wpływem udzielonego mu widzenia Augustyn zrozumiał także naturę zła, iż nie jest ono substancją, ale zepsuciem rzeczy, pozbawieniem ich w jakiejś mierze dobra. „Pojąłem, że wszystko, co stworzyłeś, jest dobre i że nie ma żadnych substancji, których byś nie stworzył"77. Umniejszenie zła istnieje tyko w bytach niższych. Dzięki temu Augustyn mógł definitywnie odrzucić dualizm manichejski, któremu tak długo ulegał. Moc jednak do pokonania zła i czynienia dobra uzyskał dopiero dzięki wierze w Jezusa Chrystusa.

\subsection{Nawrócenie jako „nowe stworzenie”}

Przekonawszy się, iż samym rozumem nie może odkryć prawdy, Augustyn zaczął uznawać coraz bardziej „,powagę świętych ksiąg”, czytał je i odkrywał ich wartość jako, ,środka” pomocnego w szukaniu Boga ${ }^{78}$. W Przeciw Akademikom wyznaje, że po silnym przynagleniu, otrzyma-

75 Augustinus, Confessiones VII 17, 23.

76 Por. V. Cilento, La mistica ellenica, w: La mistica non cristiana, red. E. Ancilli, Brescia 1969, 300-301; W. Beierwaltes, Platonizm w chrześcijaństwie, tł. P. Domański, Kęty 2003, 170.

77 Augustinus, Confessiones VII 12, 18.

78 Por. Augustinus, Confessiones VI 5, 7. 
nym pod wpływem lektury Plotyna, do dokonania ,powrotu do samego siebie", sięgnął również do Pisma Świętego i przeczytał wszystkie listy św. Pawła „W największym napięciu i z najlepszą intencją" 79 . Można przyjąć, że odsłoniła się przed nim tajemnica Jezusa Chrystusa i zarazem tajemnica „człowieka wewnętrznego”, „człowieka nowego” będąca przeciwieństwem „człowieka starego” (Kol 3,9-10; Ef 4,23-24) stworzonego na podobieństwo Adama (1Kor 15,49). Tajemnicę tę Augustyn zaczął zgłębiać tym gorliwiej, że dotyczyła ona sedna jego życia duchowego.

W Wyznaniach prarodzic Adam jest ukazany jako pierwszy grzesznik, w którym wszyscy umarli, gdyż popełniony przez niego grzech został przekazany wszystkim pochodzącym od niego potomkom przez zrodzenie. Każdy z jego rodu staje się również „Adamem” w sensie moralnym i doznaje na sobie prawa grzechu wyrażającego się w skłonności podzielonej woli do popełniania zła $(\mathrm{Rz} 7,17)^{80}$. Każdy grzech (ciężki) jest aktem pychy i zarozumiałości wobec Boga oraz nieposłuszeństwem wobec Jego woli i prawa, jest zawierzeniem sobie samemu i wyborem własnej drogi. Polega na odwróceniu się (reversio) od Boga i „szukaniu radości, wzniosłości i prawdy w stworzeniach" ". Ma w sobie moc zniewalającą i nakłada na człowieka „sidła” duchowe. „Z przewrotnej woli rodzi się złe pożądanie (libido), a kiedy się jemu służy, wytwarza się przyzwyczajenie (consuetudo), przyzwyczajenie, któremu się nie przeciwstawiamy, staje się niezwalczonym przymusem (necessitas)" ${ }^{" 82}$. Augustyn doświadczył na sobie tego skutku grzechu w całości, ponieważ żali się w Wyznaniach, iż został spętany własną wolą mająca „,moc żelaznego łańcucha”. Doświadczył też w sobie walki pomiędzy skłonnością natury a prawem ducha (Rz 7,22-24), która w sposób radykalny podjął w celu odzyskania wolności duchoweje3.

Duży wpływ na zmianę postawy Augustyna wywarł swym nauczaniem mediolański biskup Ambroży, czego potwierdzeniem było zdecydowanie się retora afrykańskiego na wstąpienie do katechumenatu zakończonego przyjęciem chrztu 23/24 kwietnia 378 roku $^{84}$. Zanim jednak do tego doszło, Augustyn długo zastanawiał się nad wartością nauki chrześcijańskiej, gdyż zrażony błędami przeszłości w owym czasie chciał uzyskać większą pewność wewnętrzną przed zdecydowaniem się na wejście na nową drogę. Nie

79 Augustinus, Contra Academicos II 5.

80 Por. Augustinus, Confessiones VIII 10, 22.

81 Augustinus, Confessiones I 20, 31.

82 Augustinus, Confessiones VIII 5, 10.

83 Por. A. Solignac, La condition de l'homme pécheur d'après saint Augustin, NRTh 88 (1956) z. 4, 383.

84 Por. A. Trapé, Centenario della conversione di Sant'Agostino: da Ippona ad Aquino, „Rivista Quadrimestrale della Pontificia Accademia di S. Tommaso” 39 (1986) z. 3, 267. 
przestawał więc $\mathrm{w}$ dalszym ciągu czerpać inspiracji duchowej z neoplatonizmu i zarazem zgłębiał coraz bardziej judeochrześcijańskie objawienie. Wyjaśnienia biskupa Ambrożego pomogły mu rozwiać niektóre wątpliwości, jak np. kwestię natury Boga i duszy, sposób rozumienia obrazu Bożego w człowieku i dostarczyły mu wiele argumentów do rozprawy z manichejczykami np. na tematy związane z filozofią przyrody ${ }^{85}$.

Łaska Boża i moc pochodząca od niej wydawały się Augustynowi przez pewien czas jakby niedostępne z powodu opanowania jego woli ,żądzą zaszczytów i pieniędzy” oraz „przywiązania do kobiety” ${ }^{\text {86. Chociaż }}$ po udzielonym mu świetle dostrzegał prawdę Bożą i pragnął coraz bardziej „trwać przy Bogu”, do czego pociągały go także budujące przykłady nawróceń innych osób (Wiktoryn, Alipiusz, Nebrydiusz) oraz styl życia mnichów i zakonników żyjących w klasztorach Mediolanu, brakowało mu jednak sił do zerwania więzów grzechu.

Te „łańcuchy” zerwała dopiero siła łaski Bożej, której doświadczył Augustyn w ogrodzie w Cassiciacum, gdzie spotykał się z przyjaciółmi. Zachęcony opatrznościowym głosem tolle, lege, tolle lege przeczytał w Liście do Rzymian św. Pawła słowa, które odebrał jako głos Boży skierowany bezpośrednio do niego. Wzywał go on do zerwania z grzechem i do przyobleczenia się w Jezusa Chrystusa (induite Dominum Iesum Christum - 13,13-14 ${ }^{87}$. W owym momencie - jak się wyraża - jego serce zostało „przebite strzałą [...] nadziemskiej miłości” i zapalone jej „ogniem” tak, iż zrodziła się w nim odpowiedź miłości, odpowiedź zdecydowanej woli miłowania Boga ${ }^{88}$. Doznał wówczas wewnętrznego oświecenia, wstąpiła w niego tak wielka ufność, że zanikła w nim „ciemność wątpienia”89. To nagłe i silne ożywienie w nim życia teologalnego miało skutek wyzwalający z tego, co go długo więziło w stworzeniach i oddzielało od Boga ${ }^{90}$. Z tą łaską Bożą Augustyn podjął od razu współpracę, gdyż napisał: ,[...] postanowiłem odnowić moje życie, pokładając nadzieję w Tobie [Boże]"91. Krótko potem przyjął chrzest, w którym został obmyty „wodą łaski”, od-

85 Sermo IX Exaemeron Ambrożego, którego słuchał Augustyn, dotyczy stworzenia świata i człowieka na obraz i podobieństwo Boże. Por. G. Banterle, Introduzione, w: Exameron, Sancti Ambrosii Episcopi Mediolanensis Opera 1, Romae 1979, 13.

86 Augustinus, Confessiones VIII 1, 2.

87 Por. Augustinus, Confessiones VIII 12, 29.

88 Por. Augustinus, Confessiones IX 2, 3; X 6, 8.

89 Augustinus, Confessiones VIII 12, 29. Por. Augustinus, Confessiones IX 2, 3.

90 Por. Augustinus, Confessiones VIII 5, 12; M. Lods, La persone du Christ dans la „,conversion” de Saint Augustin, „Recherches Augustiniennes” 9 (1976) 14.

91 Augustinus, Confessiones IX 4, 10. 
radzając się do nowego życia w Chrystusie, życia przybranym synostwem we wspólnocie Kościoła i uzyskał do tego moc Ducha ${ }^{92}$. Warto tu dodać, że do jego duchowego odrodzenia bardzo przyczyniła się jego matka Monika przez modlitwę, pokutę i cierpienie.

$\mathrm{Z}$ relacji o nawróceniu i przyjęciu chrztu wynika, iż dla Augustyna ów czas był „doświadczeniem bycia stworzonym”, otrzymaniem na nowo od Boga prawdziwego życia.

Doświadczenie wyzwolenia $\mathrm{z}$ grzechu budziło u niego wdzięczność wobec Boga i zdumienie nad sobą, nad swoją wolną wolą, którą na nowo dysponował i mógł w całej wolności powierzyć się Bogu oraz poddać Jego zbawczej woli. „O Panie, jam sługa Twój, jam sługa Twój i syn służebnicy Twojej. Potargałeś me więzy, przeto ci złożę ofiarę dziękczynną"93.

Swiadom tego, że wszystkie stworzenia są dobre, Augustyn w duchu odzyskanej wolności patrzył na nie inaczej niż wcześniej i dostrzegał, iż one wielbią Boga. Taki sposób patrzenia na stworzenia zakłada w nim wiarę i pewną zdolność wielbienia Boga. Stworzenia są dane człowiekowi, aby na nich się wspierał i nie przywiązując się do nich, wznosił się duchowo ku Bogu.

\section{Teologia i duchowość odnowionego stworzenia}

Homilie biskupa Ambrożego zwróciły uwagę Augustyna na Księgę Rodzaju i udzieliły mu wiele światła, dzięki któremu zrozumiał np. to, że nie ciało, ale dusza człowieka jest obrazem Boga ${ }^{94}$. Medytacja nad listami św. Pawła zaś ukazała mu, jaką drogę oczyszczenia winno przejść stworzenie odrodzone w chrzcie aż zostanie w nim w pełni odtworzony obraz i podobieństwo Boże. Kościół poleca w tym względzie stosowanie takich środków, jak modlitwa, sakramenty, pokuta. Owych „lekarstw” wymaga stan człowieka, który nawet po chrzcie pozostaje grzeszny i może zerwać więź z Bogiem. Jego sytuacja jest zawsze zmienna, dialektyczna. Księga dziesiąta Wyznań mówi o nieznanym wcześniej stanie duszy Augustyna. Po głębszym wglądzie w siebie wyznaje on, że się „sobie nie podoba” i wzywa Boga jako „lekarza”, by uzdrowił jego duszę. Pokłada nadzieję w Jezusie Chrystusie, prawdziwym pośredniku między Bogiem a ludźmi i oczekuje, iż przez Niego Bóg go duchowo

92 Por. Augustinus, Confessiones VIII 2, 4; VI 3, 4: ,[...] ab spiritualibus filiis tuis, quo de matre catholica per gratiam regenerasti [...].

93 Augustinus, Confessiones IX 1, 1.

94 Por. Augustinus, Confessiones VI 3, 4. 
uleczy. Czuje na sobie „brzemię” przeszłości opóźniające jego wędrówkę duchową. Najprawdopodobniej w udzielonym mu świetle Bożym rozpoznaje „to, co w nim pozostało jeszcze z ciemności (reliquias tenebrarum mearum) "95. Prosi więc Boga: „Co rozpocząłeś, tego nie zaniechaj, dopełnij to, czego mi jeszcze nie dostaje" ${ }^{\text {" }}$. Przemiana „człowieka starego" w „nowego" (Ef 4,23-24; Kol 3,9-10) jest procesem przekształcenia (reformatio) zmysłów i ducha oraz całkowitej odnowy (renovatio). Dokonuje się według zamysłu Boga oraz z uwzględnieniem możliwości wpisanych w obraz Boży w duszy ${ }^{97}$.

Prosząc Boga o łaskę odnowy wewnętrznej, Augustyn myśli zarazem o innych i postrzega ją jako motyw i cel swego działania apostolskiego ${ }^{98}$. Wspominając swoje odejście od manichejczyków, zdumiewa się nad cudownym i niepojętym postępowaniem Opatrzności Bożej $(\mathrm{J1} 2,26)$ kierującej wtedy jego krokami (Ps 36,23) i pyta: „A któż zapewni zbawienie, jeśli nie ręka Twa, którą odnawiasz to, co stworzyłeś?"'99. Biskup myśli tu o tych wszystkich, którzy potrzebują odnowy duchowej, aby mogli dojść do zbawienia. Dopiero człowiek odnowiony łaską Bożą jest w pełni człowiekiem stworzonym na obraz Boży.

\subsection{Metoda interpretacji opisu stworzenia z Księgi Rodzaju - sens alegoryczny}

Pouczony własnym doświadczeniem, że „głębia słów” Pism objawionych i wielkie tajemnice Boże nie odsłaniają się każdemu czytające$\mathrm{mu}$, ale jedynie temu, kto z wiarą stara się właściwie odczytać ich sens, Augustyn zgłębiał najpierw rożne kwestie hermeneutyczne, egzegetyczne. Powołując się często na tekst św. Pawła mówiący, iż „litera zabija, duch zaś ożywia" (2Kor 3,6), biskup Ambroży objaśniał sens alegoryczny Pisma Świętego. Zainteresował on od początku Augustyna. Nie wchodząc tu w kwestię historii egzegezy i nie przytaczając dzieł tych egzegetów (Tertulian, św. Hilary, św. Bazyli, św. Grzegorz z Nyssy), których ko-

95 Augustinus, Confessiones XI 2, 2.

96 Augustinus, Confessiones X 4, 5.

97 Por. M.-A. Vannier, Saint Augustin et la creation, w: Collectanea Augustiniana, red. B. Bruning - M. Lamberigts - J. van Houtem, Leuven 1990, 349-350.

98 Por. P. Kapusta, Articulating Creation, Artikulating Kerygma. A theological Interpretation of Evangelisation and Genesis Narrative in the Writtings of Saint Augustine of Hippo, Frankfurt am Main 2005, 242-247.

99 Augustinus, Confessiones V 7, 13: „Aut quae procuratio salutis praeter manum tuam reficientem quae fecisti?". 
mentarze Augustyn mógł czytać ${ }^{100}$, warto zauważyć, że już w De utilitate credendi, tj. w pierwszym swym dziele kapłańskim, pisał o czterech sposobach rozumienia Pisma Świętego: (a) historycznym (secundum historiam), gdy wnika się w to, co w nim zostało opisane czy opowiedziane; (b) etiologicznym (secundum aetiologiam), gdy wskazuje się przyczynę, z powodu której coś zostało uczynione lub powiedziane; (c) analogicznym (secundum analogiam), gdy wykazuje się, iż dwa Testamenty nie są ze sobą sprzeczne; (d) alegorycznym (secundum allegoriam), gdy wykazuje się, iż niektóre teksty trzeba rozumieć nie dosłownie, lecz przenośnie ${ }^{101}$. Nie wymienił tu sensu moralnego i anagogicznego, jednak gdzie indziej bardzo często według nich interpretował słowo Boże ${ }^{102}$. Można więc w pismach Augustyna znaleźć całe bogactwo złożonego sensu objawionego słowa.

Pierwszą próbą zgłębiania kosmologii i antropologii teologicznej przez Augustyna był „Antymanichejski wykład Księgi Rodzaju” (388400), w którym objaśnił w sensie przenośnym te aspekty nauki o stworzeniu, których nie zdołał wytłumaczyć w sensie właściwym ${ }^{103}$. Drugą próbą objaśnienia tych samych tekstów był jego komentarz dosłowny (393), którego jednak nie dokończył, uznając, iż było to przedsięwzięcie zbyt trudne ${ }^{104}$. Wyznania (396 lub 397) są dopiero trzecim, choć nie ostatnim ${ }^{105}$ świadectwem refleksji nad tymi tekstami podjętej w nieco innym, bo egzegetyczno-duchowym celu. Chodzi tu nie o całe dzieło, ale o ostatnie trzy księgi Wyznań zawierające medytację nad pierwszymi dwoma rozdziałami Księgi Rodzaju podjętą w powiązaniu z wcześniejszą autobiografią duchową, a w szczególności z dziełem odnowy swego życia pod wpływem miłosiernego działania Opatrzności Bożej i z zamiarem ukazania owego dzieła w formie alegorycznego objaśnienia stworzenia i jego odnowy w Chrystusie. Zostały one napisane przez Augustyna biskupa i zawierają jego pasterskie, duchowe pouczenie.

Biskup z Hippony twierdzi, że wszystkie stworzenia są dziełem dobroci i mądrości Boga, który przez swe Słowo powołał je do istnienia (J

100 W tej kwestii zob. A.-G. Hamman, Saint Augustin, la Bible et la teologie spirituelle, „Collectanea Augustiniana”, red. B. Bruning-Houtem, Leuven 1990, 780.

101 Por. Augustinus, De utilitate credendi 3, 5.

102 A. Trapè, S. Agostino esegeta: teoria e prassi, „Lateranum” 48 (1982) z. 1, 228.

103 Por. Augustinus, De Genesi contra Manicheos II 1, PL 34, 174-220. Wzmianka o powstaniu, zob. Augustinus, De Genesi ad lit teram imperfectum liber VIII 2, 5.

104 Por. Augustinus, De Genesi ad litteram imperfectum liber, PL 34, 219-246. Wzmianka o powstaniu, zob. Augustinus, Retractationes I 18 (17).

105 Około 401 roku napisze jeszcze De Genesi ad litteram (PL 34, 245-486) w tym samym stylu, co wspomniane dzieło niedokończone. 
$1,3)^{106}$. Pierwsze słowa Genesis („Na początku Bóg stworzył niebo i ziemię - Rdz 1,1) rozumie tak, że „Bóg stworzył wszystkie byty widzialne i niewidzialne"107. Sądzi, że nie można ustalić intencji Mojżesza, czyli tego, jak te słowa szczegółowo on rozumiał ,przemawiając w duchu prawdy”108. czy jako „cały widzialny świat”, czy jako „wspólną materię wszystkich rzeczy”, czy jako „bezkształtną materię” itd. Zdaniem Augustyna ważne jest, by w interpretacji słowa Bożego nie spierać się o to, jaka była intencja autora natchnionego, ale by być otwartym na ów sens, jaki światło Boże człowiekowi aktualnie ukazuje. Należy przyjąć możliwość wielu różnych interpretacji Księgi Rodzaju i to, że każda z nich może być prawdziwa, jeśli tylko ci, którzy ją przekazują, będą to czynić w prawdzie Bożej, która nie należy do żadnego człowieka, ale jest ponad wszystkimi ${ }^{109}$. Augustyna interpretacja jest podyktowana zarazem intencją złożenia Bogu „ofiary wyznań", którą ślubował, a która ma się przyczynić do obudzenia w innych pokornego i żarliwego pragnienia wielbienia Boga jako Stwórcy i Zbawcy.

Autor Wyznań jest przeciwny interpretacji materialistycznej Pisma Świętego i antropomorficznym wyobrażeniom Boga, dlatego opowiada się za interpretacją alegoryczną niektórych jego tekstów. Twierdzi, że człowiek, składając się z duszy i ciała, potrzebuje znaków materialnych, symboli ukazujących mu inny sens tekstu biblijnego niż sens odczytywany dosłownie, bezpośrednio, potrzebuje sensu głębszego, duchowego ${ }^{110}$. Biblia przypomina „cienisty sad”, w którym jest wiele „owoców ukrytych”. Skoro jakaś prawda rozumiana w jeden sposób (np. miłość Boga i bliźniego) może być oddana za pomocą wielu wyrazów materialnych, to także jakieś wyrażenie z Pisma Świętego może posiadać więcej prawdziwych interpretacji, ponieważ Duch Święty, który jest autorem Pisma Świętego, może różnym osobom ukazać różne znaczenia jakiegoś wersetu biblijnego.

Może zastanawiać, dlaczego Augustyn, będąc pod wpływem myślenia neoplatońskiego postulującego oderwanie się od rzeczywistości zmysłowej, a nawet negowanie jej na rzecz boskich idei, form, już w krótkim czasie po nawróceniu tak bardzo dowartościował obrazy, że napisał: „Opatrzność Boża stworzyła cały porządek rzeczy dla naszego zbawienia. Powinniśmy nimi posługiwać się [...] tak, jak w drodze posługujemy się pojazdem lub narzędziem, albo, by to trafniej wyrazić, byśmy miłowali to, co nas niesie, ze względu na to, do czego nas niesie" ${ }^{111}$. Autor Wyznań

\footnotetext{
106 Por. Augustinus, Confessiones XI 9, 11.

107 Augustinus, Confessiones XII 24, 33.

108 Augustinus, Confessiones XII 20, 29.

109 Por. Augustinus, Confessiones XII 18, 27; XI 25, 32.

110 Por. Augustinus, Confessiones XII 27-28; XIII 24, 36.

111 Augustinus, De Doctrina cristiana I 35, 9.
} 
chce powiedzieć, że porządek stworzenia, jeśli tylko człowiek potrafi się nim posługiwać (uti) z zachowaniem wewnętrznej wolności, okaże się mu pomocny jako ,środek wiodący” do transcendencji, do świata duchowego. To głównie z medytacji nad Biblią Augustyn czerpał obrazy oraz symbole i widział ich przydatność w osobistym dialogu z Bogiem i tę samą formę kontaktu pragnął zaproponować innym ${ }^{112}$.

\subsection{Duchowość „odnowionego stworzenia”}

„Na początku Bóg stworzył niebo i ziemię”. „Niebo” według Augustyna to owe niebo znajdujące się ponad naszą ziemią, a "niebo nad niebiosami” to „dom Boga”, Jego „mieszkanie”"113. Ziemia zaś, o której Biblia mówi, że była „niewidzialna i nieukształtowana”, (inanis et vacua - Vlg), jest „materią” „bliską nicości”, ponieważ wraz z niebem została stworzona nie z Boga ani z jakiejś substancji istniejącej wcześniej, lecz z nicości (ex nihilo $)^{114}$. Początek świata jest zarazem początkiem czasu, który Augustyn rozpatruje wnikliwie nie tylko $\mathrm{w}$ ramach historii ludzkiej, ale jeszcze bardziej od strony psychologicznej. Materia nieukształtowana jako „niepojęta otchłań", nad którą nie świeciło żadne światło, symbolizuje ludzi pogrążonych w ciemnościach niewiedzy i grzechu oraz wszelkie przejawy zła. Owa materia jest jednakże podatna na kształtowanie (formatio), aby mogła stać się „mieszkaniem dla synów ludzkich” (Ps 113,6). Ziemia razem z niebem są obrazem głowy i ciała Kościoła, duchowych i cielesnych jego członków ${ }^{115}$.

Słowa „[...] Duch Boży unosił się nad wodami” (Rdz 1,2) mówią o Duchu rozlewającym w sercu ludzkim miłość $(\mathrm{Rz} 5,5)$ i o górowaniu owej pochodzącej od Niego miłości nad „wodami” namiętności, przywiązań zmysłowych ściągających człowieka „w dół”"116, aby na nowo mógł zwrócić się ku Bogu i się z Nim zjednoczyć. Firmament, sklepienie utworzone przez Boga „w środku wód” oddzielające jedne wody od drugich (Rdz 1,6) pojmuje Augustyn jako symbol powagi Pisma Świętego ustalonej wśród pasterzy i wiernych. Firmament ten jest „,rozpostarty” nad ludźmi w doczesności na wszystkie strony świata tak, aby wszyscy mogli na

112 Por. J. Fontaine, Sens et valeur des images dans les „Confessions”, w: Augustinus Magister. Congrès International Augustinien, Paris, 21-24 septembre 1954.

Communications. „Études Augustiniennes”, Paris 1954, 125.

113 Augustinus, Confessiones XII 2, 2; XII 11, 12.

114 Augustinus, Confessiones XII 7, 28.

115 Por. Augustinus, Confessiones XIII 34, 49; XIII 12, 13.

116 Por. Augustinus, Confessiones XIII 4,5-5,6; 7, 8 . 
niego patrzeć i czerpać zeń Bożą mądrość i wskazania do zachowania przykazań Bożych oraz wielbienia miłosierdzia Bożego ${ }^{117}$. Jest on przesłonięty „chmurami” będącymi symbolem poznawania Boga w sposób niewyraźny, przez wiarę. Oddzielenie wód spod sklepienia od wód ponad sklepieniem $(\mathrm{Rdz} 1,7)$ jest symbolem uczynienia z grzeszników sprawiedliwych i oddzielenia ich od nieprawych ${ }^{118}$. Zebranie wód spod nieba $\mathrm{w}$ jedno miejsce (Rdz 1,9) objaśnia Augustyn jako symbol zebrania przez Boga, poleceniem Jego woli, ludzi niestałych, „miotających się w udręce, jak fale morza” w jedną społeczność po to, aby w owej społeczności zapanował Jego ład ${ }^{119}$. Istniała $\mathrm{i}$ istnieje potrzeba zbierania ludzi, zwoływania ich i budowania z nich wspólnoty eklezjalnej, gdyż ród wywodzący się od Adama jest jak wzburzone morze, na którym uwidacznia się ,gorzka piana przewrotnej woli ludzkiej" mogąca wprowadzać zamęt w relacje i wspólnoty międzyludzkie. Miotany jest on ciekawością i próżnością, przyjemnościami tego świata i brak mu wiary oraz wiedzy ${ }^{120}$. „Powierzchnia sucha” powstała po zebraniu wód $(\mathrm{Rdz} 1,1.9)$ jest obrazem wiernych spragnionych Boga (Ps 94,5), cechujących się gorliwością w słuchaniu słowa Bożego, pobożnością, symbolem ludzi o ,żywych duszach"121.

„Ciała niebieskie świecące na sklepieniu nieba” wyobrażają dusze tych, którzy nie upodabniali się do świata, lecz przemienili się (reformare) przez odnawianie umysłu i uwewnętrznienie prawdy oraz woli Bożej podanej w Piśmie Świętym, słowie życiodajnym i udoskonalili się $(\mathrm{Rz} 12,2)^{122}$ według wzoru Chrystusa. Nie tylko rozpoznali wolę Bożą, ale dzięki natchnieniom Ducha Świętego i Jego darom, z którymi współpracowali, dokonali wiele dobrych uczynków. Większe ciało jaśniejące na niebie, słońce $(\mathrm{Rdz} 1,16)$ jest symbolem daru mądrości słowa udzielającego ,światła przejrzystej prawdy” Bożej, księżyc jest znakiem „mowy umiejętności”, gwiazdy natomiast są znakami innych darów Bożych: wiary w Duchu Swiętym, łaski uzdrawiania, daru czynienia cudów, proroctwa, rozeznawania duchów, łaski tłumaczenia języków (1Kor 12,7-11) ${ }^{123}$. Symbol światła wskazujący ostatecznie na Boga wydaje się być dla Augustyna najważniejszym z symboli ze względu na to, Kogo wskazuje, i osobiste mistyczne doświadczenie poznania Boga. Gest oddzielenia dnia od nocy przez Stwórcę symbolizuje wezwanie do „odróżniania rzeczy dostępnych dla umysłu od

\footnotetext{
117 Por. Augustinus, Confessiones XIII 15, 16; 16-18.

118 Por. Augustinus, Confessiones XIII 34, 49.

119 Por. Augustinus, Confessiones XIII 17, 20.

120 Por. Augustinus, Confessiones XIII 17, 27.

121 Augustinus, Confessiones XIII 17, 24.

122 Por. Augustinus, Confessiones XIII 18-19.

123 Por. Augustinus, Confessiones XIII 18, 23.
} 
tych, które są dostępne zmysłom, i dusz oddanych sprawom duchowym od tych, które służą rzeczom doczesnym" ${ }^{24}$. Takiej umiejętności nie mają ludzie cieleśni kierujący się zawiścią i niezgodą, potrzebujący jako pokarmu duchowego „mleka”, ale duchowi, znający ,zamysł Chrystusowy” i potrafiący „rozsądzać wszystko” (1Kor 2,15).

Rośliny dające ziarna i drzewa rodzące owoce $(\mathrm{Rdz} 1,29)$ są symbolem uczynków miłosierdzia, w tym, w sposób szczególny pomocy, jakiej wierni udzielają swym pasterzom, kapłanom głoszącym im naukę duchową $^{125}$. Istoty żywe pływające i pełzające w wodach $(\operatorname{Rdz} 1,20)$ Augustyn objaśnia jako sakramenty, tłumacząc, iż wyobrażają one materialną stronę owych świętych znaków sprawowanych przez szafarzy, boskich posłańców symbolizowanych przez ptactwo niebieskie. Sakramenty „wpełzły” niejako „w fale pokus tego świata, aby skąpać narody w chrzcie” i „wycisnąć na nich pieczęć [...] imienia" Bożego ${ }^{126}$. Eucharystia jest symbolizowana przez rybę mistyczną, dawaną na pokarm ludziom duchowym ${ }^{127}$.

Potwory morskie ( $\mathrm{Rdz} 1,21)$ natomiast oznaczają ,,popędy duszy umarłej”, która odcięła się od źródła życia i została porwana przez grzechy tego świata, przez pychę, upodobanie w rozpuście, próżną ciekawość i tym podobne ${ }^{128}$. Skłaniające do grzechu wady mogą współistnieć w jakimś stopniu z cnotami i w ,duszy żywej” zostają w niej poddane rozumowi i mocy pochodzącej ze słowa Bożego, tak iż stają się w niej sługami władz

124 Augustinus, Confessiones XIII 18, 22.

125 Por. Augustinus, Confessiones XIII 24-25.

126 Augustinus, Confessiones XIII 20, 26.

127 Por. Augustinus, Confessiones XIII 21, 29. Augustyn wymienia więcej symboli eucharystycznych. Dla niego teologia sakramentu jest teologią znaku oraz symbolu i, w odróżnieniu od teologii współczesnej, teologii skłonnej oddzielać symbol oraz rzeczywistość, przyjmuje, że symbol, sakrament, misterium jest naprawdę tym, co oznacza. Zob. T. Camelot, Réalisme et symbolisme dans la doctrine eucharistique de saint Augustin, „Revue des Sciences Philosophique et Théologiques” 31 (1947) z. 4, 410.

128 Por. Augustinus, Confessiones XIII 21, 30. Jak wynika z powyższej interpretacji opisu stworzenia, woda jako jeden z głównych symboli w pismach Augustyna jest zarówno symbolem negatywnym, jak i pozytywnym. Taki charakter posiada ona także w Piśmie Świętym, według którego może być potęgą niszczącą (Hi 12,15), symbolem nieszczęścia grożącego człowiekowi (Ps 124), wrogich sił (Ps 42,8), ale także czymś ożywiającym i odradzającym (J 7,37; 19,34), a nawet uszczęśliwiającym (Ap 7,17; 21,6). Zob. M.-É. Boismard, Woda, w: Słownik Teologii Biblijnej, red. X. Leon-Dufour, Poznań - Warszawa 1973, 1059-1061. Wraz z postępującą odnową człowieka w Słowie wcielonym pierwsza, negatywna symbolika ustępuje miejsca drugiej, pozytywnej. Zob. H. Rondet, Le symbolism de la mer chez saint Augustin, w: Augustinus Magister. Congrès International Augustinien, Paris 21-24 septembre 1954. Communications. „Études Augustiniennes”, Paris 1954, 695. 
wyższych. Zakłada to jakąś wewnętrzną przemianę i uzyskanie zdolności panowania nad własnymi namiętnościami, czyli to, co Augustyn określa odnowieniem obrazu i podobieństwa Bożego ${ }^{129}$. Owa odnowa ma wiele stopni i dokonuje się na przestrzeni całego życia chrześcijanina.

Wyznania nie zawierają rozwiniętej nauki o obrazie Bożym w człowieku poza kilkoma wzmiankami o nim i stwierdzeniem, że triada byt (esse), poznanie (nosse) i wola (velle) są obrazem Trójcy w duszy. Augustyn zaznacza, że nie chodzi tu o obraz doskonały, jakim jest Syn zrodzony przez Boga Ojca, ale o obraz „nierówny”, analogiczny ${ }^{130}$ względem niego i ponadto zdeformowany przez grzech pierworodny. Dlatego słowa o stworzeniu człowieka biskup z Hippony interpretuje jako wezwanie do odnowienia w nim obrazu Bożego. Twierdzi, że Bóg nie powiedział: „Niech się stanie człowiek $[. .$.$] według rodzaju swego”, ale: „Uczyńmy człowieka na obraz$ i podobieństwo nasze" $(\operatorname{Rdz} 1,26)$. Chciał przez to wezwać człowieka do tego, by poznawał on swego Stwórcę, rozpoznawał Jego wolę, a otwierając się na dary Ducha Świętego, współdziałał z nimi i stawał się „,nowym człowiekiem" "131. Wzorem takiej przemiany jest św. Paweł nazwany przez Augustyna „człowiekiem odnowionym”, „żywą duszą” panującą nad swymi namiętnościami, „skrzydlatym językiem głoszącym tajemnice Boże”, człowiekiem godnym naśladowania zwłaszcza ze względu na to, że stał się doskonałym naśladowcą Chrystusa (Flp 3,17).

Gdy Bóg powoływał do życia poszczególne byty i istoty, widział, że „były dobre” (Rdz 1,12.18.25), gdy zaś ukończył dzieło stworzenia, „widział, że wszystko, co uczynił, było bardzo dobre” (Rdz 1,31). Poszczególne „spojrzenia” Boga na powoływane do bytu istoty nie są według Augustyna wieloma aktami, lecz jednym aktem Boga ${ }^{132}$, podobnie jak wskutek jednego nakazu woli dokonało się całe dzieło stworzenia świata i człowieka, Bóg bowiem patrzy na swe stworzenie „spoza czasu”, ogarnia je w całości i uznaje za bardzo dobre. Również człowiek może dostrzec dobroć

129 Por. Augustinus, Confessiones XIII 34: „[...] et deinde fidelium animam vivam per affectus ordinatos continentiae vigore formasti atque inde tibi soli mentem subditam et nullius auctoritatis humanae ad imitandum indigentem renovasti ad imaginem et similitudinem tuam praestantique intelectui rationabilem acteonem".

130 Por. Augustinus, De Trinitate VII 3, 5. W tym dziele za triadę obrazu Bożego Augustyn uznaje duszę, poznanie i miłość. Zob. P. Kołacz, Obraz Boży w człowieku w tajemnicy stworzenia wedlug św. Augustyna, ,Studia Theologica Varsaviensia” 34 (1996) z. 2, 82.

131 Por. Augustinus, Confessiones XIII 22, 32

132 Por. Augustinus, Confessiones XIII 28-29. Przeciwne twierdzenie zakładałoby zmianę w Bogu i podważałoby Jego doskonałość, dlatego należy przyjąć, że Bóg powołał do bytu wszystko, co istnieje, jednym aktem woli. Zob. Augustinus, Confessiones XII 28, 43; XIII 33, 48. 
wszystkich stworzeń, jeśli tylko będzie patrzył na nie w Duchu Świętym i dostrzeże w nich ślady Boga, a w stworzeniach rozumnych - Jego obraz. Wówczas będzie uczestniczył w powyższym widzeniu Boga.

W końcu Augustyn rozpatruje błogosławieństwo Boże i zastanawia się, dlaczego Stwórca wypowiedział słowa: „Bądźcie płodni i mnóżcie się” do ludzi stworzonych na Jego obraz i podobieństwo ( $\mathrm{Rdz} 1,27-28)$, do istot żywych pływających w wodach oraz do ptaków ( $R d z 1,22)$, a nie objął nim pozostałych stworzeń. Uważa, iż Bóg rozciągnął swe błogosławieństwo na wszystkie stworzenia, które odtwarzają się z nasienia ${ }^{133}$. Do sensu dosłownego podanego wersetu biblijnego dołącza także znaczenie symboliczne: błogosławieństwo istot żywych w wodach i ptaków w powietrzu jest znakiem tego, że umysł ludzki cechujący się twórczą płodnością może ujmowane przez siebie pojęcie interpretować na wiele różnych sposobów i dzięki temu pojmować wielorakie jego znaczenie ${ }^{134}$.

„A gdy Bóg ukończył w dniu szóstym swe dzieło [...], odpoczął dnia siódmego po całym swym trudzie, jaki podjął” (Rdz 2,2). Bóg, będąc bytem doskonałym i istniejącym w wieczności, nie męczy się, nie podlega rytmowi pracy i odpoczynku właściwemu dla człowieka, ale ,zawsze działa i zawsze spoczywa”. W słowach o odpoczynku Stwórcy Augustyn dostrzega zapowiedź tego, że wierni po dokonaniu dobrych dzieł, pełnionych mocą łaski Bożej, będą mogli odpocząć w Bogu w szabat życia wiecznego ${ }^{135}$. Będzie on dopełnieniem ich ziemskiego działania i pełnym uczestnictwem w życiu Boga oraz doświadczeniem nieustannego pokoju.

\section{Podsumowanie}

Nauka o stworzeniu zajmuje dużo miejsca w Wyznaniach i jest obecna w obu ich częściach (autobiograficznej i egzegetycznej). Z przeprowadzonej tu analizy tego dzieła można na jej temat wysnuć następujące wnioski.

133 Por. Augustinus, Confessiones XIII 24, 36-37. Augustyn dzieli byty na stworzone na początku i ,wykończone” (jak np. aniołowie, dusza ludzka) oraz na te, które będą istnieć w przyszłości, a które od początku są zawarte jedynie w „nasionach, ziarnach”. Chodzi tu o rozumienie aktu stworzenia w sensie przyczynowym (causaliter), potencjalnym (potentialiter). Zdaniem Gilsona taka teologia stworzenia ,wyłącza [...] w istocie jakiekolwiek podejrzenie o istotną twórczość w aktywności człowieka i innych bytów stworzonych”, gdyż „wszystko co, robią jest używaniem utajonych wewnętrznych sił natury”. Zob. E. Gilson, Wprowadzenie do nauki Świętego Augustyna, tł. Z. Jakimiak, Warszawa 1953, 270-271.

134 Por. Augustinus, Confessiones XIII 24, 37.

135 Por. Augustinus, Confessiones XIII 36, 51-37, 52. 
(1) Zagadnienie Boga i świata będące od początku przedmiotem zainteresowania Augustyna na drodze poszukiwania prawdy było mu długo nieznane z powodu jego zależności od manicheizmu i akceptacji materializmu oraz metafizycznego dualizmu. Dlatego oświecenie, którego później dostąpił, idąc za wskazaniami neoplatończyków, ukazujące mu prawdę o Bogu jako Tym, którego istotą jest istnienie, i odkrycie prawdy o świecie stworzonym jako drodze wstępującej do poznania Boga, prawdy o dobroci wszystkich stworzeń - przypisywane zarazem działaniu łaski Bożej - stało się dla niego pierwszą podstawą życia duchowego i uzyskanej nowej relacji do świata. Nawrócenie (conversio) natomiast, które przeżył Augustyn w Cassiciacum, udzieliło mu łaski wyzwolenia ze stanu ,niewoli”, zależności od stworzeń. Chrzest zaś przyjęty wkrótce potem oczyścił go z wszystkich grzechów. W tych wydarzeniach oraz w recepcji nauki św. Pawła o „starym” i „,nowym stworzeniu” należy upatrywać obudzenie się u Augustyna świadomości bycia stworzonym (creatio) przez Boga zarówno w sensie naturalnym, jak i duchowym.

(2) „Zraniony” słowem Bożym, które go oświeciło i dawało mu moc do życia wiarą, Augustyn wielokrotnie medytował nad tekstami biblijnymi mówiącymi o stworzeniu świata i człowieka, zgłębiał je i komentował, starając się wydobyć z nich wieloraki sens (dosłowny, moralny, duchowy, alegoryczny, anagogiczny) oraz naukę płynącą dla wiernych, jak również argumenty potrzebne w sporze z manichejczykami. Objaśniając wieloraki sens Pisma Świętego, biskup Augustyn jako doświadczony retor odwoływał się do obrazów i symboli oraz do ich zdolności budzenia u czytelników jego dzieł i słuchaczy jego kazań uczuć duchowych oraz oddziaływania na ich wolę, aby mogli udzielić pełnej odpowiedzi na miłość Boga Stwórcy i Zbawiciela.

(3) Według Augustyna czepiącego obficie z nauki św. Pawła człowiek jako stworzenie powołane do świętości potrzebuje dogłębnej przemiany (formatio) w Jezusie Chrystusie Zbawicielu dokonującej się w wewnętrznej uległości Duchowi Świętemu, do której dochodzi się we wspólnocie Kościoła przez słuchanie i interioryzację słowa Bożego, udział w sakramentach, zwłaszcza w Eucharystii, praktykę modlitwy i ascezy. Przemiana ta prowadzi do odnowienia w nim obrazu Bożego i ukształtowania pokornego oraz żarliwego pragnienia wielbienia Boga Stwórcy i Zbawcy oraz dogłębnego przyjęcia woli Bożej objawiającej się w różnych wydarzeniach zachodzących wskutek działania Opatrzności Bożej kierującej historią osobistą człowieka i historią świata.

(4) Formacja ta ma również na celu ukształtowanie w chrześcijaninie postawy zdolnej do działania w Duchu Świętym, takiej postawy, w której działanie człowieka, jego czyny stają się wyrazem działania w nim samego 
Boga. Dzięki Jego łasce uzyskują one wewnętrzną dobroć, własną wartość. Takie działanie odnowionego człowieka kształtuje civitas Dei i ukierunkowuje wszystkich jego mieszkańców na Boga. Ostatecznym powołaniem człowieka jest jednakże kontemplacja Boga w czasie „szabatu” niebieskiego, w wieczności, kiedy będzie się mógł cieszyć niezmąconym pokojem.

\section{Prawda o Bogu Stwórcy, stworzeniu i jego odnowie według Wyznań św. Augustyna}

(streszczenie)

Artykuł podejmuje temat stworzenia, który obok filozoficznego zagadnienia szukania prawdy i teologiczno-duchowej confessio stanowi jedno z głównych zagadnień Wyznań Augustyna. Najpierw wskazuje na ważność tego zagadnienia w tym dziele i poszukuje sposobu powiązania go z dwoma odmiennymi tematycznie częściami Wyznań: autobiograficzną i egzegetyczną. Dalej ukazuje Augustyna „krętą drogę” poszukiwania prawdy o Stwórcy i stworzeniu wiodącą przez czas błędów młodości i okres zagubienia się w sekcie manichejczyków (materializm, dualizm metafizyczny). Objaśnia zrodzone u Augustyna pod wpływem neoplatonizmu doświadczenie ,powrotu do samego siebie” i uzyskanie światła prawdy o Stwórcy oraz stworzeniu, a potem, pod wpływem lektury Słowa Bożego, uzyskanie łaski nawrócenia jako daru „nowego stworzenia”. W ostatniej części artykułu przybliżono, na podstawie ostatnich ksiąg Wyznań, teologię i duchowość „nowego stworzenia”, objaśniając je w sensie dosłownym i alegorycznym.

Słowa kluczowe: Augustyn; Wyznania; stworzenie; nawrócenie; teologia stworzenia; odnowa stworzenia; formacja duchowa

\section{The Truth about God the Creator, Creation and Its Renewal, according to Confessions of St. Augustine}

(summary)

This article raises the theme of creation, which, besides the philosophical question of seeking truth and theological-spiritual confessio, is one of the main issues of Augustine's Confessions. First, it indicates the importance of this issue in this work and is looking for a way to connect it with two thematically different parts of Confessions, autobiographical and exegetic. Next, he shows Augustine's "winding road" of seeking the truth about the Creator and creation, leading through the time of youth's mistakes and the period of getting lost in the Manichean sect (Materialism, the metaphysical Dualism). He also explains affecting Augustine, under the influence of Neoplatonism, the experience of "returning to himself" and gaining the light of the truth about the Creator and creation, and then attaining, under the influence of readings of the Word of God, the grace of conversion as a gift of the "new creation". In the last part of the article, the author, based on the last books 
of Confessions, makes more familiar the theology and spirituality of the "new creation" explained in a literal and allegorical sense.

Keywords: Augustine; Confessions; creation; conversion; theology of creation; renewal of creation; spiritual formation

\section{Bibliografia:}

\section{Źródla:}

Augustinus, Confessiones, PL 32, 659-868; tł. Z. Kubiak, Św. Augustyn, Wyznania, Warszawa 1992.

Augustinus, Contra Academicos, PL 322, 905-958; tł. K. Augustyniak, Św. Augustyn, Przeciw Akademikom, w: Św. Augustyn, Dialogi filozoficzne, Kraków 1999, 57-150.

Augustinus, De civitate Dei, PL 41, 13-804; tł. W. Kubicki, Św. Augustyn, Państwo Boże, Kęty 1998.

Augustinus, De Trinitate, PL 42, 819-1098; tł. M. Stokowska, Św. Augustyn, O Trójcy Świętej, Kraków 1996.

Augustinus, De utilitate credendi, PL 42, 65-92.

Augustinus, Enarrationes in Psalmos, PL 36-37, 67-1966; tł. J. Sulowski, Św. Augustyn, Objaśnienia Psalmów, Warszawa 1986.

Augustinus, Retractationes, PL 32, 583-656; tł. J. Kalinowski: Św. Augustyn, Sprostowania, w: Św. Augustyn, O nauce chrześcijańskiej. Sprostowania, PSP 22, Warszawa 1979, 149-308.

\section{Opracowania:}

Banterle G., Introduzione, w: Exameron, Sancti Ambrosii Episcopi Mediolanensis Opera 1, Romae 1979, 13-20.

Boismard M.-E., Woda, w: Słownik Teologii Biblijnej, red. X. Leon-Dufour, Poznań Warszawa 1973, 1058-1062.

Camelot T., Réalisme et symbolisme dans la doctrine eucharistique de saint Augustin, „Revue des Sciences Philosophique et Théologiques” 31 (1947) z. 4, 394-410.

Cilento V., La mistica ellenica, w: La mistica non cristiana, red. E. Ancilli, Brescia 1969, 187-304.

Feldmann E., Confessiones, AL I fasc. 7/8, 1134-1199.

Fontaine J., Sens et valeur des images dans les „Confessions”, w: Augustinus Magister. Congrès International Augustinien, Paris, 21-24 septembre 1954. Communications. „Études Augustiniennes”, Paris 1954, 117-126.

Gilson E., Notes sur l'être et le temps chez Saint Augustin, „Recherches Augustiniennes”, II. Supplement à la „Revue des Sciences des Études Augustiniennes”, Paris 1962, 205-223. 
Gilson E, Wprowadzenie do nauki Świętego Augustyna, tł. Z. Jakimiak, Warszawa 1953. Kapusta P., Articulating Creation, Artikulating Kerygma. A theological Interpretation of Evangelisation and Genesis Narrative in the Writtings of Saint Augustine of Hippo, Frankfurt am Main 2005.

Kołacz P., Obraz Boży w człowieku w tajemnicy stworzenia wedlug św. Augustyna, „Studia Theologica Varsaviensia" 34 (1996) z. 2, 75-89.

Kowalczyk S., Człowiek i Bóg w nauce św. Augustyna, Warszawa 1987.

Legowicz J., Historia filozofii starożytnej Grecji i Rzymu, Warszawa 1986.

Lods M., La personne du Christ dans la ,conversion” de Saint Augustin, „Recherches Augustiniennes" 9 (1976) 3-34.

Martelet G., Pierworodny wszelkiego stworzenia, w: „Communio” 2 (1982) z. 4, 17-45.

Mayer C., Creatio, creator, creatura, AL II fasc. 1/2, 56-116.

Müller G.L., Doświadczenie Boga jako początek wiary chrześcijańskiej, „Communio”, 16 (1996) z. 5, 100-114.

Pizzolato L.P., Le „,Confessioni” di Sant'Agostino. Da biografia a 'confessio', Milano 1968.

Reta, J.O., Aspects théologique de la conversion, StPatr 33 (1997) 190-212.

Rondet H., Le symbolism de la mer chez saint Augustin, w: Augustinus Magister. Congrès International Augustinien, Paris 21-24 septembre 1954. Communications. „Études Augustiniennes", Paris 1954, 691-701.

Schmid P., Wierze, w Boga, Stworzyciela nieba i ziemi, „Communio” 2 (1982) z. 4, 3-16.

Solignac A., La condition de l'homme pécheur d'après saint Augustin, NRTh 88 (1956) z. 4, 359-385.

Trapé A., Introduzione, w: Sant'Agostino, Le Confessioni, red. M. Skutella, tł. C. Carena, Città Nuova Editrice, Roma 1965, s. IX-CXXI.

Vannier M.-A., Saint Augustin et la creation, w: Collectanea Augustiniana, red. B. Brunning - M. Lamberigts - J. Houtem, Leuven 1990, 349-370.

Wawrzyniak, A., Egzystencja, w: Leksykon Filozofii Klasycznej, red. J. Herbut, Lublin 1997, 138-140. 
